\title{
The potency of blumeatin and luteolin as caspase-1 inhibitor by molecular docking
}

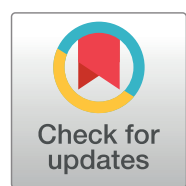

\author{
I Putu Ari Anggara Catur Pratama $\mathbb{D}^{\mathbb{1}}$, I Made Harimbawa Putra $\mathbb{D}$, Luh Wayan Sita Pujasari $\mathbb{C}_{\text {, }}$ \\ Komang Dian Mertasari Dewi 1 , Ni Putu Linda Laksmiani \\ Departement of Pharmacy, Faculty of Mathematics and Natural Science, Udayana University, Bukit Jimbaran, Badung, Bali \\ 80361, Indonesia \\ *Corresponding author: Jl. Kampus Bukit Jimbaran, Badung, Bali 80361, Indonesia. Email: laksmini@unud.ac.id
}

\begin{abstract}
COVID-19 infection induces inflammation by increasing cytokines such as IL-1 $\beta$, IL-6, IL-18, IFN- $\gamma$, and TNF-a. IL-1 is generated by the involvement of caspase-1. Therefore, caspase- 1 inhibitor can be potential for inflammation therapy caused by COVID-19 infection. This study aims to determine the potential of blumeatin and luteolin as anti-inflammatory agents by inhibiting caspase-1 using a molecular docking approach. This study was carried out by caspase-1 (PDB ID: 1RWK) preparation, blumeatin and luteolin structure optimization, docking protocol validation, and docking of blumeatin and luteolin on caspase-1. Bluematin and luteolin had a binding affinity of $-5,63 \mathrm{kcal} / \mathrm{mol}$ and $-5,93 \mathrm{kcal} / \mathrm{mol}$, lower than Q158 native ligand $(-3.92 \mathrm{kcal} /$ mol). Similar amino acid residues in hydrogen bonds interaction were observed between Q158 native ligand, blumeatin, and luteolin with caspase-1 (GLN 283 and ARG 179). Blumeatin and luteolin are potentially anti-inflammation agents through the inhibition of the caspase- 1 in silico.
\end{abstract}

Keywords: blumeatin, caspase-1, cytokines storm, in silico, luteolin, molecular docking.

\section{Introduction}

COVID-19 infection causes inflammation of the lungs by increasing cytokines [1]. Cytokines have an important role in the immune response, including defense against viral infections. However, COVID-19 infection can result in an overproduction of cytokines (cytokine storm) that can develop into pneumonia. Cytokine storms play a role in causing acute respiratory distress syndrome (ARDS) [2]. ARDS is a critical condition that needs a prompt and appropriate therapeutic intervention to prevent acute lung damage, multi-organ failure, and death [3].

Cytokine storm is a critical, life-threatening condition that requires intensive care. Cytokine storms are characterized by the clinical presentation of excessive systemic inflammation, hyperferritinemia, hemodynamic instability, and multi-organ failure. The trigger for a cytokine storm is an uncontrolled immune response that results in the continuous activation and expansion of immune cells, lymphocytes, and macrophages. Clinical findings of a cytokine storm are caused by pro-inflammatory cytokines such as IL-1, IL-6, IL-18, IFN- $\gamma$, and TNF- $\alpha$ [4].

IL-1 is a potent inflammatory cytokine involved in immunological responses to both innate and adaptive immunity. There are two similar molecules of IL-1, IL- $1 \alpha$, and IL- $1 \beta$ [5]. IL- $1 \beta$ is expressed in many tissues, including lung tissues [6]. IL-1 $\beta$ is produced by interleukin-1 $\beta$ converting enzyme (ICE), also known as caspase-1, that can be activated due to OCVID-19 infection [7]. Caspase- 1 is a cysteine protease that converts pro-inflammatory IL- $1 \beta$ into active and mature IL-1 $\beta$ [8].

The caspase-1/ICE inhibitor can potentially be used for lung inflammation therapy caused by COVID-19 infection. Caspase-1 may be inhibited by several compounds like natural flavonoids [9]. Blumeatin and luteolin (Figure 1) are natural flavonoid that can be found in sembung plant (Blumea balsamifera L.) [10]. Blumeatin has various biological activities such as hepatoprotective, superoxide radical scavenging, antioxidant, and antityrosinase [11,12]. Meanwhile, luteolin has superoxide radical scavenging, antioxidant and antityrosinase activity [12].

The inhibitory activity of blumeatin and luteolin against caspase- 1 can be determined by using in silico molecular docking, a computational simulation used to know the binding between a ligand and protein [13]. This study aims to determine the potential effect of blumeatin and luteolin as anti-inflammation by 
<smiles>COc1cc(O)c2c(c1)O[C@H](c1cc(O)cc(O)c1)CC2=O</smiles>

b<smiles>O=c1cc(-c2ccc(O)c(O)c2)oc2cc(O)cc(O)c12</smiles>

Figure 1. Natural flavonoids compounds (a) blumeatin, (b) luteolin

a

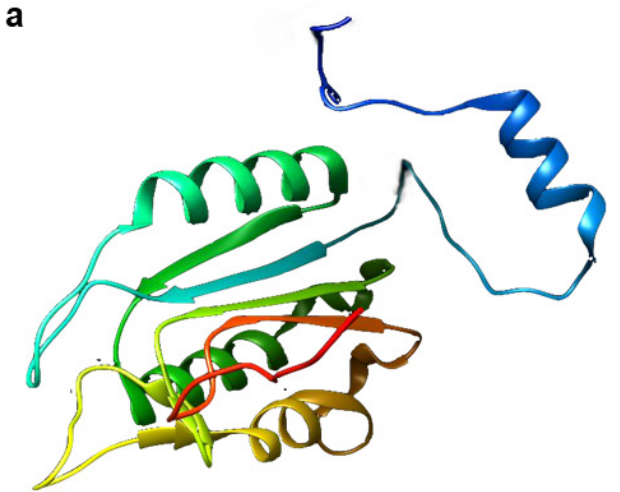

b

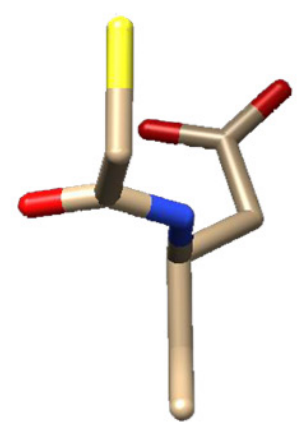

Figure 2. Structure of protein and native ligand. (a) caspase-1, (b) Q158

inhibition of caspase-1 using a molecular docking approach.

\section{Methods}

\section{Preparation of the protein}

Caspase-1 protein structure was downloaded from https://www.rcsb.org/. Caspase-1 (PDB ID: 1RWK) was prepared by using Chimera 1.10 .1 and separated from 3-(2-mercapto-acetylamino)-4-oxo-pentanoic acid (Q158) native ligand.

\section{Optimization of blumeatin and luteolin}

The three-dimensional (3D) structures of blumeatin and luteolin were downloaded from https://pubchem. ncbi.nlm.nih.gov/. The structures were optimized using HyperChem 8 with Austin Model 1 (AM1) semi-empirical computational method and singlepoint calculations and geometry optimization.

\section{Validation of docking method}

The molecular docking procedure was validated using the Autodock Tools application (Autodock4 and
Autogrid4) through redocking the native ligand Q158 to the prepared caspase- 1 protein. The grid box size was set to $\mathrm{x}=30 \AA, \mathrm{y}=20 \AA, \mathrm{z}=30 \AA$ with the $\mathrm{x}$, $y$, and $\mathrm{z}$ coordinate centers were $33.016 \AA$, $60.302 \AA$, and $4.934 \AA$, respectively. The validation parameter of the molecular docking method was the value of root mean square deviation (RMSD), which is valid if the value $\leq 2.0 \AA[14]$.

\section{Blumeatin and luteolin docking to caspase-1}

The molecular docking of the prepared blumeatin and luteolin was performed using Autodock 4.2 program. The docking process was conducted with a similar grid box size as validation step. The docking results showed the conformations with the lowest binding energy in complex with caspase-1 protein.

\section{Data analysis}

The molecular docking results were binding energy and visualization of the interaction between blumeatin or luteolin and caspase-1 protein. The lower the binding energy, the stronger the interaction of the 
a

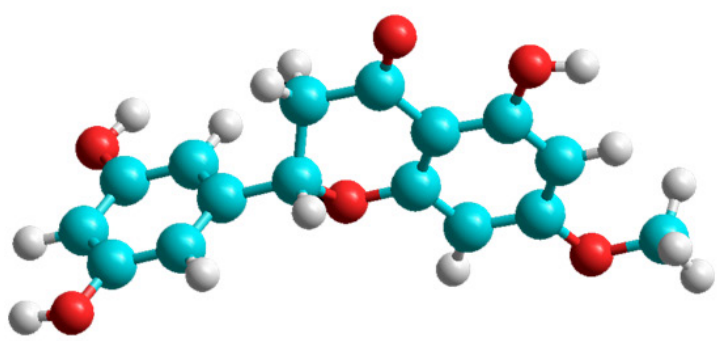

C

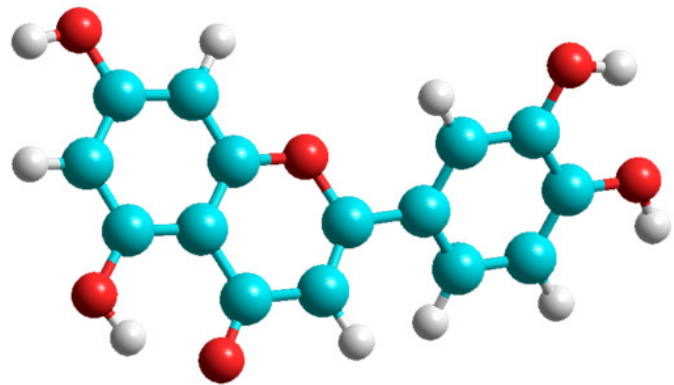

b

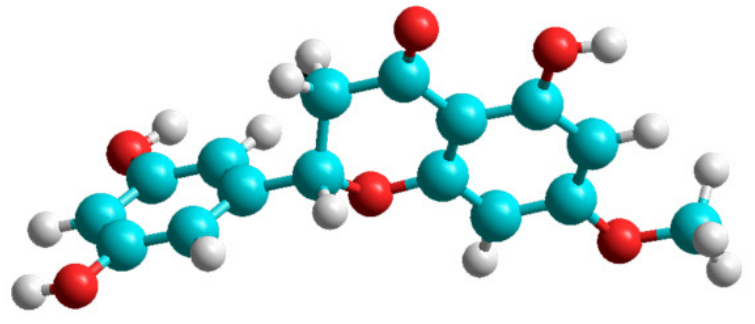

d

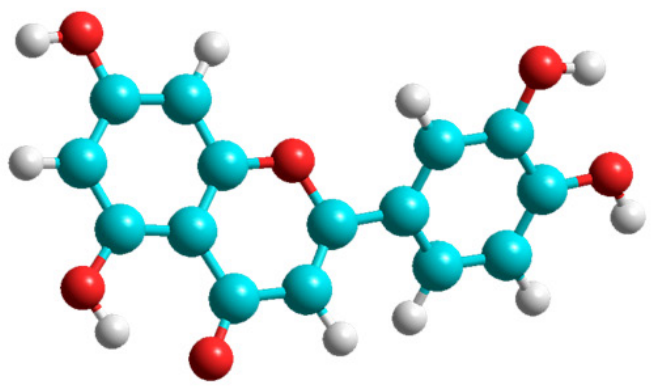

Figure 3. The results of single-point calculation and geometry optimization of the optimized structures. (a-b) blumeatin, (c-d) luteolin
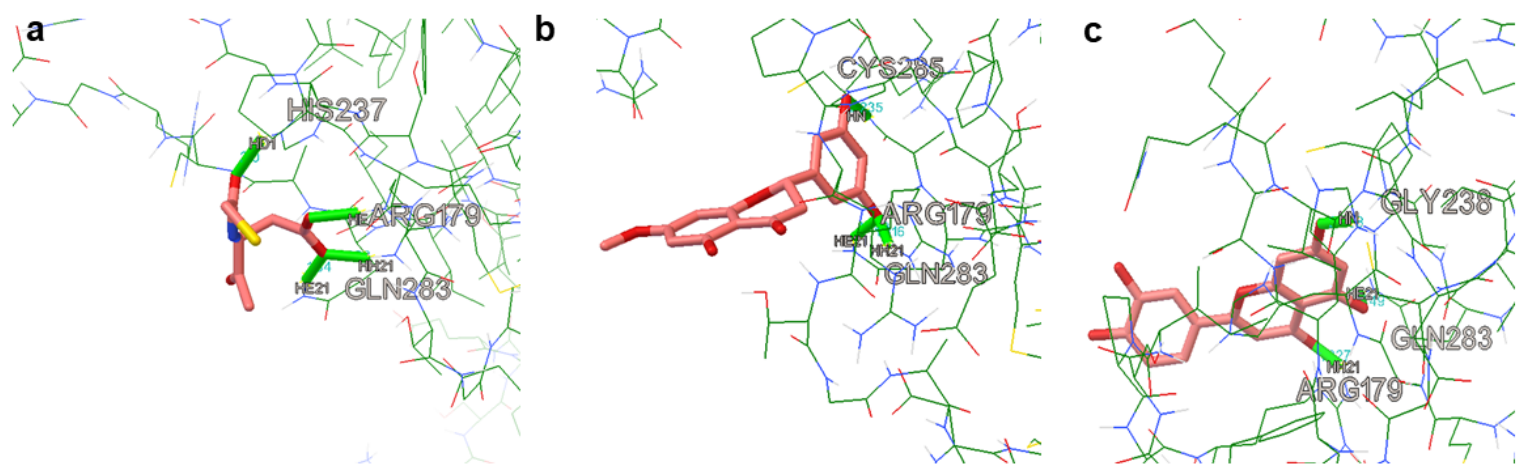

Figure 4. 3D visualization of docking results. (a) Q158, (b) blumeatin, (c) luteolin

compounds with protein, indicating the potential as anti-inflammatory agents.

\section{Results}

\section{Caspase-1 preparation}

The preparation of caspase-1 protein aims to separate the protein from Q158 native ligand as well as to obtain the Q158 for the docking validation. The prepared caspase-1 and Q158 native ligand are displayed in Figure 2.

\section{Optimization of blumeatin and luteolin}

The optimization of blumeatin resulted in total single point energy and geometry optimization of $-3996 \mathrm{kcal} / \mathrm{mol}$ and $-4006 \mathrm{kcal} / \mathrm{mol}$, respectively.
Meanwhile, the total single point energy and geometry optimization obtained of luteolin were $-3606 \mathrm{kcal} / \mathrm{mol}$ and $-3814 \mathrm{kcal} / \mathrm{mol}$ (Figure 3).

\section{Validation of molecular docking}

The docking method was validated by redocking Q158 native ligand to caspase- 1 . The validation produced 10 conformations with different RMSD values and binding energy. Conformation 6 had the lowest RMSD value of $1.97 \AA$ (Table 2), suggesting the docking method is valid.

\section{Docking of blumeatin and luteolin to caspase-1}

The optimized blumeatin and luteolin were then docked to the caspase- 1 protein. The docking process 
produced ten conformations with binding affinity $-5.63 \mathrm{kcal} / \mathrm{mol}$ and $-5.93 \mathrm{kcal} / \mathrm{mol}$ for blumeatin and luteolin, respectively (Table 3 ). Visualization analysis indicated blumeatin and luteolin interacted with caspase-1 by hydrogen bonding through ARG 179 and GLN 283 residues (Figure 4).

Table 2. The results of molecular docking validation

\begin{tabular}{|c|c|c|c|c|c|}
\hline Ligand & Conformations & $\begin{array}{l}\text { Binding energy } \\
\text { (kcal/mol) }\end{array}$ & RMSD (Å) & $\begin{array}{l}\text { Amino acid } \\
\text { residues }\end{array}$ & $\begin{array}{c}\text { Groups in } \\
\text { hydrogen bonds }\end{array}$ \\
\hline & \multirow{3}{*}{1} & \multirow{3}{*}{-4.17} & \multirow{3}{*}{3.51} & GLN 283 & HE21-O11 \\
\hline \multirow[t]{36}{*}{ Q158 } & & & & ARG 179 & $\mathrm{HH} 21-\mathrm{O} 11$ \\
\hline & & & & ARG 179 & HE-O12 \\
\hline & \multirow{4}{*}{2} & \multirow{4}{*}{-4.41} & \multirow{4}{*}{2.43} & ARG 179 & HE-N4 \\
\hline & & & & HIS 237 & HD1-O8 \\
\hline & & & & GLN 283 & HE21-011 \\
\hline & & & & ARG 179 & $\mathrm{HH} 21-\mathrm{O} 11$ \\
\hline & \multirow{4}{*}{3} & \multirow{4}{*}{-4.31} & \multirow{4}{*}{2.71} & ARG 179 & HE-N4 \\
\hline & & & & HIS 237 & HD1-O8 \\
\hline & & & & GLN 283 & HE21-O11 \\
\hline & & & & ARG 179 & $\mathrm{HH} 21-\mathrm{O} 11$ \\
\hline & \multirow{3}{*}{4} & \multirow{3}{*}{-4.7} & \multirow{3}{*}{2.71} & GLN 283 & HE21-O8 \\
\hline & & & & CYS 285 & $\mathrm{HN}-\mathrm{O} 12$ \\
\hline & & & & ARG 179 & $\mathrm{HH} 21-\mathrm{O} 8$ \\
\hline & \multirow{4}{*}{5} & \multirow{4}{*}{-4.17} & \multirow{4}{*}{2.58} & ARG 179 & HE-N4 \\
\hline & & & & HIS 237 & HD1-O8 \\
\hline & & & & GLN 283 & HE21-O12 \\
\hline & & & & ARG 179 & $\mathrm{HH} 21-\mathrm{O} 12$ \\
\hline & \multirow{4}{*}{$6^{*}$} & \multirow{4}{*}{-3.92} & \multirow{4}{*}{1.97} & ARG 179 & HE-O11 \\
\hline & & & & HIS 237 & HD1-013 \\
\hline & & & & GLN 283 & HE21-012 \\
\hline & & & & ARG 179 & $\mathrm{HH} 21-\mathrm{O} 12$ \\
\hline & \multirow{4}{*}{7} & \multirow{4}{*}{-4.2} & \multirow{4}{*}{2.3} & CYS 285 & $\mathrm{HN}-012$ \\
\hline & & & & GLN 283 & HE21-O13 \\
\hline & & & & GLY 238 & HN-O12 \\
\hline & & & & ARG 179 & $\mathrm{HH} 21-\mathrm{O} 13$ \\
\hline & \multirow{3}{*}{8} & \multirow{3}{*}{-4.63} & \multirow{3}{*}{2.4} & GLN 283 & HE21-O8 \\
\hline & & & & CYS 285 & $\mathrm{HN}-012$ \\
\hline & & & & HIS 237 & HD1-011 \\
\hline & \multirow{4}{*}{9} & \multirow{4}{*}{-4.34} & & CYS 285 & HN-O11 \\
\hline & & & 235 & GLN 283 & HE21-O13 \\
\hline & & & 2.35 & GLY 238 & $\mathrm{HN}-\mathrm{O} 11$ \\
\hline & & & & ARG 179 & $\mathrm{HH} 21-\mathrm{O} 13$ \\
\hline & & & & CYS 285 & $\mathrm{HN}-\mathrm{O} 12$ \\
\hline & 10 & -471 & 274 & ARG 179 & HE-O13 \\
\hline & 10 & -4.71 & 2.14 & GLN 283 & HE21-O8 \\
\hline & & & & HIS 237 & HD1-011 \\
\hline
\end{tabular}


Table 3. Results of blumeatin and luteolin molecular docking against caspase-1

\begin{tabular}{|c|c|c|c|c|c|}
\hline Ligand & Conformations & $\begin{array}{l}\text { Binding energy } \\
\text { (kcal/mol) }\end{array}$ & RMSD (Å) & $\begin{array}{l}\text { Amino acid } \\
\text { residues }\end{array}$ & $\begin{array}{c}\text { Groups in } \\
\text { hydrogen bonds }\end{array}$ \\
\hline \multirow[t]{10}{*}{ Blumeatin } & 1 & -5.38 & 0.18 & $\begin{array}{l}\text { GLY } 238 \\
\text { CYS } 285\end{array}$ & $\begin{array}{l}\mathrm{HN}-\mathrm{O} \\
\mathrm{HN}-\mathrm{O}\end{array}$ \\
\hline & 2 & -5.62 & 0.04 & $\begin{array}{l}\text { GLN-283 } \\
\text { CYS-285 } \\
\text { ARG } 179\end{array}$ & $\begin{array}{c}\text { HE21-O } \\
\text { HN-O } \\
\mathrm{HH} 21-\mathrm{O}\end{array}$ \\
\hline & $3^{*}$ & -5.63 & 0.0 & $\begin{array}{l}\text { GLN-283 } \\
\text { CYS-285 } \\
\text { ARG } 179\end{array}$ & $\begin{array}{c}\text { HE21-O } \\
\text { HN-O } \\
\mathrm{HH} 21-\mathrm{O}\end{array}$ \\
\hline & 4 & -5.43 & 0.17 & CYS 285 & $\mathrm{HN}-\mathrm{O}$ \\
\hline & 5 & -5.61 & 0.05 & $\begin{array}{l}\text { ARG } 179 \\
\text { GLN } 283\end{array}$ & $\begin{array}{l}\mathrm{HH} 21-\mathrm{O} \\
\mathrm{HE} 21-\mathrm{O}\end{array}$ \\
\hline & 6 & -5.6 & 0.03 & $\begin{array}{l}\text { ARG } 179 \\
\text { HIS } 237 \\
\text { GLN } 283 \\
\text { ARG } 179 \\
\end{array}$ & $\begin{array}{c}\mathrm{HE}-\mathrm{O} 11 \\
\mathrm{HD} 1-\mathrm{O} 13 \\
\mathrm{HE} 21-\mathrm{O} 12 \\
\mathrm{HH} 21-\mathrm{O} 12\end{array}$ \\
\hline & 7 & -5.43 & 0.0 & $\begin{array}{l}\text { GLY } 238 \\
\text { CYS } 285 \\
\end{array}$ & $\begin{array}{l}\mathrm{HN}-\mathrm{O} \\
\mathrm{HN}-\mathrm{O}\end{array}$ \\
\hline & 8 & -5.62 & 0.01 & $\begin{array}{l}\text { ARG } 179 \\
\text { GLN } 283 \\
\text { CYS } 285\end{array}$ & $\begin{array}{c}\mathrm{H} H 21-\mathrm{O} \\
\mathrm{HE} 21-\mathrm{O} \\
\mathrm{HN}-\mathrm{O}\end{array}$ \\
\hline & 9 & -6.61 & 0.09 & $\begin{array}{l}\text { ARG } 179 \\
\text { GLN } 283 \\
\text { CYS } 285 \\
\end{array}$ & $\begin{array}{c}\mathrm{HH} 21-\mathrm{O} \\
\mathrm{HE} 21-\mathrm{O} \\
\mathrm{HN}-\mathrm{O}\end{array}$ \\
\hline & 10 & -5.62 & 0.21 & $\begin{array}{l}\text { ARG } 179 \\
\text { GLN } 283\end{array}$ & $\begin{array}{l}\mathrm{HH} 21-\mathrm{O} \\
\mathrm{HE} 21-\mathrm{O}\end{array}$ \\
\hline \multirow[t]{10}{*}{ Luteolin } & $1^{*}$ & -5.93 & 0.0 & $\begin{array}{l}\text { ARG } 179 \\
\text { GLY } 238 \\
\text { GLN } 283\end{array}$ & $\begin{array}{c}\mathrm{H} 21-\mathrm{O} \\
\mathrm{HN}-\mathrm{O} \\
\mathrm{HE} 21-\mathrm{O}\end{array}$ \\
\hline & 2 & -5.93 & 0.05 & $\begin{array}{l}\text { ARG } 179 \\
\text { GLY } 238 \\
\text { GLN } 283\end{array}$ & $\begin{array}{c}\mathrm{H} \text { H21-O } \\
\text { HN-O } \\
\text { HE21-O }\end{array}$ \\
\hline & 3 & -5.93 & 0.02 & $\begin{array}{ll}\text { ARG } & 179 \\
\text { GLY } 238 \\
\text { GLN } 283\end{array}$ & $\begin{array}{c}\mathrm{HH} 21-\mathrm{O} \\
\mathrm{HN}-\mathrm{O} \\
\mathrm{HE} 21-\mathrm{O}\end{array}$ \\
\hline & 4 & -5.93 & 0.05 & $\begin{array}{ll}\text { ARG } & 179 \\
\text { GLY } & 238 \\
\text { GLN } 283\end{array}$ & $\begin{array}{c}\mathrm{HH} 21-\mathrm{O}, \mathrm{O} \\
\mathrm{HN}-\mathrm{O} \\
\mathrm{HE} 21-\mathrm{O}\end{array}$ \\
\hline & 5 & -5.93 & 0.05 & $\begin{array}{l}\text { ARG } 179 \\
\text { GLY } 238 \\
\text { GLN } 283\end{array}$ & $\begin{array}{c}\mathrm{HH} 21-\mathrm{O}, \mathrm{O} \\
\mathrm{HN}-\mathrm{O} \\
\mathrm{HE} 21-\mathrm{O}\end{array}$ \\
\hline & 6 & -5.92 & 0.1 & $\begin{array}{l}\text { ARG } 179 \\
\text { GLY } 238 \\
\text { GLN } 283\end{array}$ & $\begin{array}{c}\mathrm{HH} 21-\mathrm{O}, \mathrm{O} \\
\mathrm{HN}-\mathrm{O} \\
\mathrm{HE} 21-\mathrm{O}\end{array}$ \\
\hline & 7 & -5.93 & 0.01 & $\begin{array}{l}\text { ARG } 179 \\
\text { GLY } 238 \\
\text { GLN } 283\end{array}$ & $\begin{array}{c}\mathrm{HH} 21-\mathrm{O}, \mathrm{O} \\
\mathrm{HN}-\mathrm{O} \\
\mathrm{HE} 21-\mathrm{O}\end{array}$ \\
\hline & 8 & -5.93 & 0.02 & $\begin{array}{l}\text { ARG } 179 \\
\text { GLY } 238 \\
\text { GLN } 283\end{array}$ & $\begin{array}{c}\mathrm{HH} 21-\mathrm{O} \\
\mathrm{HN}-\mathrm{O} \\
\mathrm{HE} 21-\mathrm{O}\end{array}$ \\
\hline & 9 & -5.92 & 0.12 & $\begin{array}{l}\text { ARG } 179 \\
\text { GLY } 238 \\
\text { GLN } 283\end{array}$ & $\begin{array}{c}\mathrm{HH} 21-\mathrm{O}, \mathrm{O} \\
\mathrm{HN}-\mathrm{O} \\
\mathrm{HE} 21-\mathrm{O}\end{array}$ \\
\hline & 10 & -5.92 & 0.09 & $\begin{array}{l}\text { ARG } 179 \\
\text { GLY } 238 \\
\text { GLN } 283\end{array}$ & $\begin{array}{c}\mathrm{HH} 21-\mathrm{O}, \mathrm{O} \\
\mathrm{HN}-\mathrm{O} \\
\mathrm{HE} 21-\mathrm{O}\end{array}$ \\
\hline
\end{tabular}


Table 4. The summary of docking results of Q158 native ligand, bluematin, and luteolin on caspase-1

\begin{tabular}{|c|c|c|c|}
\hline Ligands & $\begin{array}{l}\text { Binding energy } \\
\text { (kcal/mol) }\end{array}$ & $\begin{array}{l}\text { Amino acid } \\
\text { residues }\end{array}$ & $\begin{array}{c}\text { Groups in hydrogen } \\
\text { bonds }\end{array}$ \\
\hline Native ligand Q158 & -3.92 & $\begin{array}{l}\text { ARG } 179 \\
\text { HIS } 237 \\
\text { GLN } 283 \\
\text { ARG } 179\end{array}$ & $\begin{array}{c}\mathrm{HE}-\mathrm{O} 11 \\
\mathrm{HD} 1-\mathrm{O} 13 \\
\mathrm{HE} 21-012 \\
\mathrm{HH} 21-012\end{array}$ \\
\hline Blumeatin & -5.63 & $\begin{array}{l}\text { GLN-283 } \\
\text { CYS-285 } \\
\text { ARG } 179\end{array}$ & $\begin{array}{c}\text { HE21-O } \\
\text { HN-O } \\
\mathrm{HH} 21-\mathrm{O}\end{array}$ \\
\hline Luteolin & -5.93 & $\begin{array}{l}\text { ARG } 179 \\
\text { GLY } 238 \\
\text { GLN } 283\end{array}$ & $\begin{array}{c}\mathrm{HH} 21-\mathrm{O} \\
\mathrm{HN}-\mathrm{O} \\
\mathrm{HE} 21-\mathrm{O}\end{array}$ \\
\hline
\end{tabular}

\section{Discussion}

Our results showed that blumeatin and luteolin have a lower binding affinity $(-5.63 \mathrm{kcal} / \mathrm{mol}$ and $-5.93 \mathrm{kcal} / \mathrm{mol})$ than Q158 native ligand $(-3.92 \mathrm{kcal} /$ mol) (Table 4). Blumeatin and luteolin have similar hydrogen-bonding interactions with Q158 native ligand through ARG 179 and GLN 283 residues. These results suggested blumeatin and luteolin docked in the same active site of Q158 native ligand in the caspase-1 target protein.

An in silico molecular docking study of rosmarinic acid (RA) to caspase-1 (PDB ID: 1RWK) showed that docking score was $25.0 \pm 0.05$ and showed interaction with GLY 238, HIS 237, SER 339, and ARG 341 residues [15]. Another docking study to caspase-1 (PDB ID: 1RWK) also showed compound 2-(4-\{2-[(phenylthio) acetyl]-carbonohydrazonoyl\}-phenoxy)acetamide has interaction through GLN 283, ARG 179, ARG 341, HIS 237, and ASP 288 [16]. An in vitro study of the anti-inflammatory activity of blumeatin and luteolin was carried out by the dual-luciferase assay method. The result showed that blumeatin $(0.01 \mathrm{mmol} / \mathrm{L}$ and 0.1 $\mathrm{mmol} / \mathrm{L})$ and luteolin $(0.01 \mathrm{mmol} / \mathrm{L}, 0.1 \mathrm{mmol} / \mathrm{L}$ and $1 \mathrm{mmol} / \mathrm{L}$ ) have anti-inflammatory activity by inhibit NF- $\mathrm{kB}$ expression. Ingenuity pathway analysis (IPA) predicted that blumeatin has an anti-inflammatory effect related to Hif-1a [17]. Luteolin and luteolin-7$\mathrm{O}$-glycoside have been reported for anti-inflammatory effects due to TNF- $\alpha$ inhibition [18].

Based on this study, blumeatin and luteolin are predicted to have activity as the anti-inflammation agent. The interaction that occurs between blumeatin and luteolin on the active site of caspase- 1 shows inhibitory activity so that it can inhibit the maturation of IL- $1 \beta$, thereby decreasing the mature IL- $1 \beta$ expression.

\section{Conclusion}

The binding energy of blumeatin and luteolin with caspase-1 was lower than Q158 native ligand, indicating these compounds have an affinity for caspase-1. Blumeatin and luteolin are potentially anti-inflammation agents based on the in silico study against caspase- 1 .

\section{Acknowledgment}

The authors thank to Direktorat Jenderal Pembelajaran dan Kemahasiswaan, Kementerian Riset, Teknologi, dan Pendidikan Tinggi Republik Indonesia that funded for this research in the Program Kreativitas Mahasiswa 2021 (Grant number 015/E2/ PPK/SPPK/PKM/2021).

\section{Declaration of interest}

None.

\section{Author contributions}

IPAACP conceptualized the study design, IPAACP, IMHP, LWSP, KDMSD investigated the data, IPAACP, LWSP wrote original draft, IMPH, KDMSD, NPLL reviewed and edited final version, NPLL supervised all experiments. All authors have read the final manuscript.

Received: 20 September 2021

Accepted: 4 December 2021

Published online: 14 January 2022 


\section{References}

1. Tang Y, Liu J, Zhang D, Xu Z, Ji J, Wen C. Cytokine Storm in COVID-19: The Current Evidence and Treatment Strategies. Front Immunol. 2020;11: 1708. https://doi. org/10.3389/fimmu.2020.01708

2. Azmi NU, Puteri MU, Lukmanto D. Cytokine Storm in COVID-19: An Overview, Mechanism, Treatment Strategies, and Stem Cell Therapy Perspective. Pharm Sci Res. 2020;7: 1-11. https://doi.org/10.7454/psr.v7i4.1092

3. Etti AE, Assy N, Idan C. Interleukin-1. In: John Wiley \& Sons, Ltd, editor. eLS. Wiley; 2001. pp. 1-9. https://doi. org/10.1002/9780470015902.a0028193

4. Shimizu M. Clinical features of cytokine storm syndrome. In: Cron RQ, Behrens EM, editors. Cytokine Storm Syndrome. Cham: Springer International Publishing; 2019. pp. 31-41. https://doi.org/10.1007/978-3-030-220945_3

5. Fields JK, Günther S, Sundberg EJ. Structural Basis of IL-1 Family Cytokine Signaling. Front Immunol. 2019;10: 1412. https://doi.org/10.3389/fimmu.2019.01412

6. Kaneko N, Kurata M, Yamamoto T, Morikawa S, Masumoto J. The role of interleukin-1 in general pathology. Inflamm Regen. 2019;39: 12. https://doi.org/10.1186/s41232-0190101-5

7. Rodrigues TS, de Sá KSG, Ishimoto AY, Becerra A, Oliveira S, Almeida L, et al. Inflammasomes are activated in response to SARS-CoV-2 infection and are associated with COVID-19 severity in patients. J Exp Med. 2021;218. https://doi.org/10.1084/jem.20201707

8. Lawson MA, McCusker RH, Kelley KW. Interleukin-1 beta converting enzyme is necessary for development of depression-like behavior following intracerebroventricular administration of lipopolysaccharide to mice. J Neuroinflammation. 2013;10: 54. https://doi. org/10.1186/1742-2094-10-54

9. White JB, Beckford J, Yadegarynia S, Ngo N, Lialiutska T, d'Alarcao M. Some natural flavonoids are competitive inhibitors of Caspase-1, -3 and -7 despite their cellular toxicity. Food Chem. 2012;131: 1453-1459. https://doi. org/10.1016/j.foodchem.2011.10.026
10. Pang Y, Wang D, Fan Z, Chen X, Yu F, Hu X, et al. Blumea balsamifera--a phytochemical and pharmacological review. Molecules. 2014;19: 9453-9477. https://doi.org/10.3390/ molecules19079453

11. Xu J, Jin D, Liu C, Xie C, Guo Y, Fang L. Isolation, characterization, and NO inhibitory activities of sesquiterpenes from Blumea balsamifera. J Agric Food Chem. 2012;60: 8051-8058. https://doi.org/10.1021/ jf302530u

12. Nessa F, Ismail Z, Mohamed N. Xanthine oxidase inhibitory activities of extracts and flavonoids of the leaves of Blumea balsamifera. Pharm Biol. 2010;48: 14051412. https://doi.org/10.3109/13880209.2010.487281

13. Meng X-Y, Zhang H-X, Mezei M, Cui M. Molecular docking: a powerful approach for structure-based drug discovery. Curr Comput Aided Drug Des. 2011;7: 146157. https://doi.org/10.2174/157340911795677602

14. Jain AN, Nicholls A. Recommendations for evaluation of computational methods. J Comput Aided Mol Des. 2008;22: 133-139. https://doi.org/10.1007/s10822-008-9196-5

15. Jeong H-J, Choi Y, Kim M-H, Kang I-C, Lee J-H, Park $\mathrm{C}$, et al. Rosmarinic acid, active component of DansamEum attenuates ototoxicity of cochlear hair cells through blockage of caspase-1 activity. PLoS One. 2011;6: e18815. https://doi.org/10.1371/journal.pone.0018815

16. Kim H-Y, Nam S-Y, Jang J-B, Choi Y, Kang I-C, Kim H-M, et al. 2-(4-\{2-[(phenylthio)acetyl $]$ carbonohydrazonoyl $\}$ phenoxy)acetamide as a new lead compound for management of allergic rhinitis. Inflamm Res. 2016;65: 963-973. https://doi.org/10.1007/s00011-016-0979-1

17. Liu J, Wang S, Tan W, Lv B, Dai Y, Wang Y, et al. Dualscreening of anti-inflammatory and antioxidant active ingredients of shenxiang suhe pill and its potential multi-target therapy for coronary heart disease. Biomed Pharmacother. 2020;129: 110283. https://doi.org/10.1016/j. biopha.2020.110283

18. Park CM, Song Y-S. Luteolin and luteolin-7-O-glucoside protect against acute liver injury through regulation of inflammatory mediators and antioxidative enzymes in GalN/LPS-induced hepatitic ICR mice. Nutr Res Pract. 2019;13: 473-479. https://doi.org/10.4162/nrp.2019.13.6.473 